\title{
Uji Aktivitas Antioksidan Krim Kombinasi Ekstrak Daun Jambu Biji (Psidium guajava L.) Dan Ekstrak Umbi Wortel (Daucus carota L.) Dengan Menggunakan Metode DPPH (2,2-diphenyl-1- picrylhydrazyl)
}

\author{
Antioxidant Activity Test Of Combination Cream Of Guava Leave \\ Extract (Psidium guajava L.) And Carrot Extract (Daucus carota L.) \\ Using DPPH (2,2-diphenyl-1-picrylhydrazyl) Method
}

\author{
Siti Pandanwangi TW *), Arsyad Bachtiar, Deni Firmansyah \\ STF Muhammadiyah Cirebon \\ Jl Cideng Indah No. 3 Cirebon
}

\begin{abstract}
ABSTRAK
Antioksidan merupakan suatu senyawa yang dapat meredam radikal bebas yang menyebabkan penuaan dini. Daun jambu biji dan umbi wortel salah satu tanaman yang berkhasiat sebagai antioksidan. Penelitian ini bertujuan untuk mengetahui aktivitas antioksidan krim kombinasi ekstrak daun jambu biji dan ekstrak umbi wortel dengan menggunakan metode DPPH. Daun jambu biji dan umbi wortel yang sudah dimaserasi dibuat dalam bentuk sediaan krim kombinasi. Formulasi I perbandingan ekstraks daun jambu biji : ekstrak umbi wortel 1\%:3\%, Formula II perbandingannya $2 \%: 2 \%$, dan Formula III perbandingannya $3 \%: 1 \%$. Kombinasi krim ini diuji aktivitas antioksidannya dengan alat spektrofotometri UV-Vis. Krim kombinasi ekstrak daun jambu biji formula I memiliki aktivitas antioksidan sebesar 102,69 ppm, Formula II memiliki aktivitas antioksidan sebesar $82,52 \mathrm{ppm}$, formula III memiliki aktivitas antioksidan sebesar 132,45 ppm, kontrol negatif memiliki aktivitas antioksidan sebesar 380,28 ppm, sedangkan untuk kontrol positif memiliki aktivitas antioksidan sebesar 13,32 ppm. Hasil penelitian menunjukan bahwa krim kombinasi ekstrak daun jambu biji dan ekstrak umbi wortel pada konsentrasi 2\%: $2 \%$ memiliki aktivitas antioksidan tertinggi sebesar $82,52 \mathrm{ppm}$.
\end{abstract}

Kata kunci : antioksidan, radikal bebas, daun jambu biji, umbi wortel, DPPH, $\mathrm{IC}_{50}$

\begin{abstract}
Antioxidants are a compound that can reduce free radicals that cause premature aging. Guava leaves and carrot one of the plants are efficacious as an antioxidant. This study aims to determined the antioxidant activity of cream combination of guava leave extract and carrot extract by used DPPH method. Guava leaves and carrot macerated are made in a combination of cream. Formulation I extract of guava leave: carrot extract $1 \%: 3 \%$, Formula II $2 \%: 2 \%$, and Formula III 3\%: $1 \%$ comparison. The combination of this cream tested its antioxidant activity with UV-Vis spectrophotometry. The cream of guava leaves extract of formula I had antioxidant activity of 102,69 ppm, Formula II had antioxidant activity of $82,52 \mathrm{ppm}$, formula III had antioxidant activity of 132, $45 \mathrm{ppm}$, negative control had antioxidant activity of $380,28 \mathrm{ppm}$, while for positive control had antioxidant activity equal to $13,32 \mathrm{ppm}$. The results showed that the combination cream of guava leaves extract and carrot extract at concentration $2 \%: 2 \%$ had the highest antioxidant activity of $82.52 \mathrm{ppm}$.
\end{abstract}


Keywords: antioxidant, free radical, guava leaves, carrot, DPPH, $\mathrm{IC}_{50}$

\section{Penulis korespondensi:}

Siti Pandanwangi

Sekolah Tinggi Farmasi Muhammadiyah Cirebon

Jl. Cideng Indah No.3 Cirebon

Email: sitipandanwangitw@yahoo.com, No.Hp 087725550618

\section{PENDAHULUAN}

Antioksidan adalah substansi yang mampu menangkal atau meredam radikal bebas dan mencegah terjadinya kerusakan yang disebabkan oleh radikal bebas (Winarsi, 2007). Secara alami beberapa jenis tumbuhan merupakan antioksidan, hal ini dapat ditemukan pada beberapa jenis sayuran, buah-buahan segar beberapa jenis tumbuhan dan rempah-rempah. Tanaman dan buah-buahan terbukti berpotensi sebagai antioksidan karena mengandung berbagai zat seperti karoten, flavonoid dan komponen fenolik lain, serta vitamin $\mathrm{C}$ dan $\mathrm{E}$ (Prakash dkk, 2001).

Daun jambu biji (Psidium Gujava L) mengandung metabolit sekunder kuersetin yang memiliki khasiat sebagai antioksidan. Kuersetin adalah salah satu zat aktif kelas flavonoid golongan flavonol yang secara biologis amat kuat. Kuersetin dipercaya dapat melindungi tubuh dari kondisi stress oksidatif dengan cara menstabilkan ROS. Kandungan antioksidan dari daun jambu biji dapat merendam radikal bebas yang dapat merusak kulit. (Kosasih dkk., 2006).

Karotenoid, provitamin A, merupakan salah satu senyawa antioksidan alami yang banyak terdapat dalam umbi wortel (Daucus carota L.) (Andarwulan dan Koswara, 1992). Kandungan karotenoid dalam wortel dapat dilihat dari intensitas warnanya, yaitu semakin jingga warna wortel maka semakin banyak kandungan karotenoidnya (Rubatzky dan Yamaguchi, 1998). Karotenoid yang dikandung tidak hanya beta karoten tetapi juga alfa karoten, gamma karoten, zeta karoten, dan likopen yang dapat memberikan perlindungan pada tubuh terhadap pengaruh negatif dari radikal bebas (Medical Economics Company, 2000).

Dalam penelitian sebelumnya tentang Uji Aktivitas Antioksidan dan Stabilitas Fisik Gel Ekstrak Terpurifikasi Daun Jambu Biji (Psidium guajava L.) bahwa pada konsentrasi 2\% memiliki aktivitas antioksidan dengan nilai IC50 yang terbesar. (Suryani dkk, 2015). Dalam penelitian sebelumnya tentang krim antioksidan ekstrak umbi wortel bahwa pada konsentrasi $2 \%$ memiliki pengukuran aktivitas antioksidan yang paling tinggi. (Maulina, 2011). Tujuan penelitian adalah untuk mengetahui apakah krim kombinasi ekstrak daun jambu biji (Psidium Guajava L.) dan ekstrak umbi wortel (Daucus Carota L.) memiliki aktivitas antioksidan terhadap DPPH (2,2-diphenyl-1-picrylhydrazyl). Tujuan lain untuk mengetahui pada konsentrasi berapakah kombinasi ektrak daun jambu biji (Psidium Guajava L.) dan ekstrak umbi wortel (Daucus Carota L.) memiliki aktivitas antioksidan paling tinggi.

\section{METODE PENELITIAN}

\section{Alat dan Bahan}

Alat : maserator, blender (Philip), neraca analitik, spektrofotometer UV-VIS (Biobase), termometer.

Bahan : daun jambu biji, umbi wortel, propilen glikol (teknis), TEA (teknis), asam stearat (teknis), aquadest (teknis), vaselin album (teknis), cera alba (teknis), metil paraben 
(farmasetik), radikal DPPH (Pro analisis), etanol 70\% (teknis), dan Vitamin C Injeksi (Kimia Farma).

\section{Jalannya Penelitian}

Pengumpulan bahan, pembuatan simplisia daun jambu biji dan umbi wortel, pembuatan ekstrak daun jambu biji, pembuatan ekstrak umbi wortel, pembuatan krim kombinasi ekstrak daun jambu dan umbi wortel, pembuatan larutan DPPH, pengujian stabilitas krim, uji antioksidan krim.

\section{Pembuatan Simplisia}

Menyiapkan daun jambu biji (Psidium guajava $\mathrm{L}$ ) dan umbi wortel (Daucus carota L) yang segar. Daun jambu biji dan umbi wortel dibersihkan dari zat pengotor (sortasi basah), kemudian dicuci dengan air mengalir, tiriskan. Daun jambu biji dan umbi wortel potong kecil-kecil kemudian dikeringkan di oven suhu $40^{\circ} \mathrm{C}$. Lakukan sortasi kering pada masing-masing simplisia. Menimbang dan mencatat bobot kering simplisia daun jambu biji dan umbi wotel. Simplisia daun jambu biji dan umbi wortel dihaluskan dengan cara memblendernya sampai menjadi serbuk.

\section{Pembuatan Ekstrak}

a. Ekstrak Daun Jambu Biji

Masukan 100 gram simplisia daun jambu biji (Psidium guajava L) yang telah diserbukkan. Masukan ke dalam maserator. Tambahkan etanol 70\% sebanyak $700 \mathrm{ml}$. Biarkan simplisia terendam pelarut dalam maseretor selama 5 hari sambil sesekali diaduk. Setelah 5 hari keluarkan maserat dari maserator, dan ditampung kedalam eryenmeyer saring dengan menggunakan kain planel untuk memisahkan ampas dengan maseratnya, ukur volume maserat (filtrat 1). Kemudian ampas masukan lagi kedalah maserator, dan ditambahkan etanol $300 \mathrm{ml}$ biarkan selama 2 hari sambil sesekali diaduk.. Setelah 2 hari keluarkan maserat dari maserator saring menggunakan kain flanel (filtrat 2) Gabungkan filtrat 1 dengan filtrat 2 dalam wadah penampung, kemudian diuapkan hingga memperoleh ekstrak kental. Menghitung rendemen ekstrak yang diperoleh.

b. Ekstrak Umbi Wortel

Masukan 100 gram simplisia umbi wortel (Daucus carota L) yang telah diserbukkan. Masukan kedalam maserator. Tambahkan etanol $70 \%$ sebanyak 700 ml. Biarkan simplisia terendam pelarut dalam maseretor selama 5 hari sambil sesekali diaduk. Setelah 5 hari keluarkan maserat dari maserator, dan ditampung kedalam eryenmeyer saring dengan menggunakan kain planel untuk memisahkan ampas dengan maseratnya, ukur volume maserat (filtrat 1). Kemudian ampas masukan lagi kedalah maserator, dan ditambahkan etanol $300 \mathrm{ml}$ biarkan selama 2 hari sambil sesekali diaduk. Setelah 2 hari keluarkan masetar dari maserator saring menggunakan kain flanel (filtrat 2). Gabungkan filtrat 1 dengan filtrat 2 dalam wadah penampung, kemudian diuapkan hingga memperoleh ekstrak kental. Menghitung rendemen ekstrak yang diperoleh. 


\section{Pembuatan Formula Krim}

Tabel I. Formula Krim Ekstrak Daun Jambu Biji Dan Umbi Wortel

\begin{tabular}{lcccc}
\hline \multirow{2}{*}{\multicolumn{1}{c}{ Bahan }} & \multicolumn{4}{c}{ Formula $($ gram $)$} \\
\cline { 2 - 5 } & $\mathrm{F} 1$ & $\mathrm{~F} 2$ & $\mathrm{~F} 3$ & $\mathrm{~K}-$ \\
\hline Ekstrak daun jambu biji & 1 & 2 & 3 & - \\
Ekstrak umbi wortel & 3 & 2 & 1 & - \\
Asam stearat & 7,5 & 7,5 & 7,5 & 7,5 \\
Cera alba & 7,5 & 7,5 & 7,5 & 7,5 \\
Vaselin album & 5 & 5 & 5 & 5 \\
Triethanolamin (TEA) & 1,5 & 1,5 & 1,5 & 1,5 \\
Propylen gycol & 7,5 & 7,5 & 7,5 & 7,5 \\
Metil paraben & 0,075 & 0,075 & 0,075 & 0,075 \\
Aquadest & 50 & 50 & 50 & 50 \\
\hline
\end{tabular}

Keterangan : F1 : Formula 1 (ekstrak daun jambu biji dan ekstrak umbi wortel $1: 3$ )

F2 : Formula 2 (ekstrak daun jambu biji dan ekstrak umbi wortel $2: 2$ )

F3 : Formula 2 (ekstrak daun jambu biji dan ekstrak umbi wortel $3: 1$ )

\section{Cara pembuatan formula krim:}
a. Timbang semua bahan
b. Fase minyak (cera alba, asam stearat, vaselin album) dileburkan di atas penangas air sampai lebur.
c. Fase air (Propilenglikol, Metil paraben, TEA) dilarutkan di atas penangas air sampai larut
d. Masukan fase minyak dan fase air ke dalam mortir panas
e. Gerus sampai terbentuk massa krim yang homogen
f. Tambahkan esktrak daun jambu biji dan wortel (masing-masing dengan perbandingan 1:3;2: 2 dan 3:1) sedikit demi sedikit gerus sampai homogen.
g. Masukan ke dalam wadah krim

\section{Uji stabilitas krim}

Stabilitas formula krim diamati pada hari ke-0 sesaat setelah pembuatan krim selesai yaitu dilakukan pada suhu $25^{\circ} \mathrm{C}$. Uji stabilitas dengan cycling test juga dilakukan dengan parameter uji organoleptis, homogenitas, $\mathrm{pH}$, daya sebar krim, daya lekat krim. Uji Cycling test dilakukan dengan menyimpan sampel krim pada suhu $4^{\circ} \mathrm{C}$ selama 24 jam kemudian dipindahkan ke dalam oven bersuhu $40^{\circ} \mathrm{C}$ selama 24 jam, waktu selama penyimpanan dua suhu tersebut dianggap satu siklus. Uji stabilitas dilakukan sebanyak 6 siklus kemudian diamati ada tidaknya pemisahan fase dan inversi (Suryani, 2013)

a. Uji organoleptis

Pengamatan organoleptik sediaan krim meliputi pengamanata terhadap bau, warna, dan tekstur sediaan. Adapun pelaksanaanya menggunakan subjek responden dengan kriteria tertentu, menghintung persentase masing-masing kriteria yang diperoleh, serta mengambil keputusan analisis statistik.

b. Uji homogenitas

Uji ini dilakukan dengan meletakkan sejumlah zat tertentu diatas kaca yang berskala. Kemudian diamati ada partikel atau tidak. Jika tidak ada partikel terpisah maka sediaan tersebut dinyatakan homogen.

c. Uji pH

Uji pH dalam pengujian ini dilakukan menggunakan indikator universal. $\mathrm{pH}$ sediaan topikal yang baik yaitu 4,5-6,5. 
d. Uji daya sebar

Uji ini dilakukan dengan cara sejumlah zat tertentu diletakkan diatas kaca yang berskala. Kemudian bagian atasnya diberi kaca yang sama dan ditingkatkan bebannya dengan diberi rentang waktu 1-2 menit. Selanjutnya diameter penyebaran diukur pada setiap penambahan beban, saat sediaan berhenti menyebar dalam waktu tertentu secara beratur.

e. Uji Daya Lekat

Sebanyak 0,3 gram krim dioleskan diatas gelas obyek yang sudah diketahui luasnya.Diletakkan gelas obyek yang lain pada krim tersebut kemudian ditekan dengan beban $1 \mathrm{~kg}$ selama 1 menit. Dipasang gelas obyek tersebut pada alat uji kemudian dipasang beban seberat 80 gram dan dicatat waktu hingga kedua gelas obyek terpisah (Engelina, 2013).

f. Uji Viskositas

Pengukuran dilakukan dengan menggunakan viscometer Brookfield dan menggunakan spindle no. 6. Krim dimasukan ke dalam wadah gelas, kemudian spindle yang telah dipasang diturunknsehingga batas spindle tercelup ke dalam krim. Kecepatan alat $10 \mathrm{rpm}$, kemudian dibaca dan dicatat skala ketika jarum merah yang bergerak telah stabil. Uji viskositas krim pada penelitian ini dilakukan pada hari ke0 .

\section{Uji Aktivitas Antioksidan Krim Kombinasi ekstrak daun jambu biji dan ekstrak umbi wortel}

a. Pembuatan Larutan (Persiapan Awal)

1. Pembuatan Larutan DPPH 100 ppm

Timbang $10 \mathrm{mg}$ DPPH, larutkan dengan etanol 70\% hingga $100 \mathrm{ml}$ dalam labu ukur kemudian kocok hingga homogen sehingga diperoleh larutan dengan konsentrasi 100 ppm lalu simpan ditempat gelap.

2. Penentuan Panjang Gelombang Maksimum DPPH

Masukkan $2 \mathrm{ml}$ larutan DPPH kedalam tabung reaksi, tambahkan $2 \mathrm{ml}$ etanol, kocok hingga homogen dan dituang kedalam kuvet lalu diukur pada panjang gelombang 400-700 $\mathrm{nm}$.

3. Pembuatan Larutan Vitamin C 100 ppm

Timbang $10 \mathrm{mg}$ serbuk vitamin $\mathrm{C}$ murni, larutkan dengan aquadest hingga 100 $\mathrm{ml}$ dalam labu ukur sehingga diperoleh konsentrasi 100 ppm sebagai larutan induk. Kocok hingga homogen. Kemudian dari larutan induk dibuat larutan dengan seri konsentrasi 2 ppm, 4 ppm, 6 ppm, 8 ppm dan 10 ppm dengan cara dipipet masing-masing $0,2 \mathrm{ml} ; 0,4 \mathrm{ml} ; 0,6 \mathrm{ml} ; 0,8 \mathrm{ml}$; dan $1 \mathrm{ml}$, lalu dilarutkan dengan $10 \mathrm{ml}$ etanol $70 \%$.

4. Pembuatan Larutan Blanko

Masukkan $2 \mathrm{ml}$ larutan DPPH kedalam tabung reaksi, kemudian tambahakan etanol $70 \%$ sebanyak $2 \mathrm{ml}$, lalu kocok hingga homogen dan disimpan ditempat gelap selama 30 menit.

b. Pengukuran Aktivitas Antioksidan

1. Pengukuran aktivitas antioksidan vitamin $\mathrm{C}$ terhadap radikal bebas DPPH

Sebanyak $2 \mathrm{ml}$ larutan vitamin $\mathrm{C}$ dengan konsentrasi 2 ppm, 4 ppm, 6 ppm, 8 ppm dan 10 ppm, masing-masing ditambahkan 2 ml larutan DPPH, dikocok hingga homogen lalu disimpan ditempat gelap selama 30 menit. Setelah itu serapan diukur dengan spektrofotometri UV-Vis pada panjang gelombang maksimumnya.

2. Pengukuran aktivitas antioksidan sampel terhadap radikal bebas DPPH 
Krim ekstrak kombinasi daun jambu biji dan wortel ditimbang sebanyak $10 \mathrm{mg}$ dari masing-masing konsentrasi kemudian dimasukan kedalam labu ukur dan ditambahkan etanol $70 \%$ hingga $100 \mathrm{ml}$, kocok hingga homogen. Kemudian disaring menggunakan kertas saring hingga jernih dan ditampung filtratnya. Dilakukan pengenceran sehingga diperoleh larutan dengan konsentrasi $10 \mathrm{ppm}, 20 \mathrm{ppm}, 30 \mathrm{ppm}, 40 \mathrm{ppm}$ dan $50 \mathrm{ppm}$. Kemudian dimasukan dalam labu ukur dan dicukupkan hingga $10 \mathrm{ml}$ dengan etanol $70 \%$. Mengambil $2 \mathrm{ml}$ dari masing-masing konsentrasi, lalu ditambahkan $2 \mathrm{~mL}$ larutan DPPH (2,2-difenil-1-picrylhidrazyl). Larutan dihomogenkan, kemudian diinkubasi dalam ruangan gelap selama 30 menit . Masing-masing larutan diukur absorbansinya pada panjang gelombang maksimal.

Nilai absorbansi yang muncul kemudian dimasukkan ke rumus \% inhibisi, kemudian dibuat kurva standar/kurva baku antara konsentrasi (ppm) dengan $\%$ inhibisi.

$$
\% \text { inhibisi }=\frac{\text { Absorbansi blanko-Absorbansi sampel }}{\text { Absorbansi blanko }} \times 100 \%
$$

Setelah itu dimasukkan ke persamaan regresi linier untuk mengetahui nilai $\mathrm{IC}_{50}$ dengan rumus :

$$
\mathrm{Y}=\mathrm{bx}+\mathrm{a}
$$

Keterangan :

$\mathrm{Y}=$ Persen penangkapan radikal sampel

$\mathrm{x}=$ Konsentrasi sampel

$\mathrm{a}=$ Titik potong kurva pada sumbu Y (Intercep)

$\mathrm{b}=$ Kemiringan kurva (Slope)

\section{c. Penentuan Nilai $\mathrm{IC}_{50}$ (Inhibition Concentration)}

Setelah mendapatkan nilai absorbansi dan \% inhibisi terhadap DPPH, selanjutnya dilakukan penentuan nilai $\mathrm{IC}_{50}$ dengan memasukkan konsentrasi sebagai $\mathrm{X}$ dan $\%$ inhibisi sebagai $\mathrm{Y}$ sehingga diperoleh nilai a dan $\mathrm{b}$ pada persamaan regresi $\mathrm{Y}=\mathrm{bx}+\mathrm{a}$. Kemudian disubstitusikan nilai $\mathrm{Y}$ dengan 50 pada persamaan tersebut, dan nilai $X$ yang akan diperoleh sebagai nilai $\mathrm{IC}_{50}$ (Maulina,2011).

\section{Analisis Data}

Analisa data aktivitas antioksidan dianalisis menggunakan persamaan regresi (regresi linier sederhana) yaitu $Y=a x+b$. Analisis regresi merupakan suatu model matematis yang dapat digunakan untuk mengetahui bentuk hubungan antar dua variabel atau lebih. Analisis regresi bertujuan untuk membuat perkiraan atau prediksi nilai suatu variabel (variabel penden/terikat) melalui variabel yang lain (variabel independen/bebas). Koefisien determinasi berguna untuk mengetahui seberapa besar variabel dependen/terikat (Y) dapat dijelaskan oleh variabel independen/bebas (X). Semakin besar nilai $r^{2}$, maka semakin baik variabel independen memprediksi variabel dependen. Besarnya nilai $\mathrm{r}^{2}$ antara 0 sampai 1 .

\section{HASIL DAN PEMBAHASAN}

Berikut ini adalah hasil penelitian uji stabilitas dari krim ekstrak daun jambu biji dan krim ekstrak umbi wortel sesuai formula masing-masing pada siklus dan suhu tertentu 
Tabel II. Hasil uji organoleptis sediaan

\begin{tabular}{|c|c|c|c|c|c|c|}
\hline \multirow[b]{2}{*}{ Sediaan } & \multirow[b]{2}{*}{ Siklus } & \multirow[b]{2}{*}{$\begin{array}{l}\text { Hari } \\
\text { ke- }\end{array}$} & \multicolumn{4}{|c|}{ Pengamatan } \\
\hline & & & Warna & Bau & Tekstur & Bentuk \\
\hline \multirow{7}{*}{$\mathrm{F} 1$} & $0\left(25^{\circ} \mathrm{C}\right)$ & 1 & Putih tulang & Khas & Lembut & Semi padat \\
\hline & 1 & 2 & Putih agak kecoklatan & Khas & Lembut & Semi padat \\
\hline & 2 & 4 & Putih agak kecoklatan & Khas & Lembut & Semi padat \\
\hline & 3 & 6 & Putih agak kecoklatan & Khas & Lembut & Semi padat \\
\hline & 4 & 8 & Putih agak kecoklatan & Khas & Lembut & Semi padat \\
\hline & 5 & 10 & Putih agak kecoklatan & Khas & Lembut & Semi padat \\
\hline & 6 & 12 & Putih agak kecoklatan & Khas & Lembut & Semi padat \\
\hline \multirow{7}{*}{ F2 } & $0\left(25^{\circ} \mathrm{C}\right)$ & 1 & Putih kecoklatan & Khas & Lembut & Semi padat \\
\hline & 1 & 2 & Putih kecoklatan & Khas & Lembut & Semi padat \\
\hline & 2 & 4 & Putih kecoklatan & Khas & Lembut & Semi padat \\
\hline & 3 & 6 & Putih kecoklatan & Khas & Lembut & Semi padat \\
\hline & 4 & 8 & Putih kecoklatan & Khas & Lembut & Semi padat \\
\hline & 5 & 10 & Putih kecoklatan & Khas & Lembut & Semi padat \\
\hline & 6 & 12 & Putih kecoklatan & Khas & Lembut & Semi padat \\
\hline \multirow{7}{*}{ F3 } & $0\left(25^{\circ} \mathrm{C}\right)$ & 1 & Putih kecoklatan pekat & Khas & Lembut & Semi padat \\
\hline & 1 & 2 & Putih kecoklatan pekat & Khas & Lembut & Semi padat \\
\hline & 2 & 4 & Putih kecoklatan pekat & Khas & Lembut & Semi padat \\
\hline & 3 & 6 & Putih kecoklatan pekat & Khas & Lembut & Semi padat \\
\hline & 4 & 8 & Putih kecoklatan pekat & Khas & lembut & Semi padat \\
\hline & 5 & 10 & Putih kecoklatan pekat & Khas & Lembut & Semi padat \\
\hline & 6 & 12 & Putih kecoklatan pekat & Khas & Lembut & Semi padat \\
\hline \multirow{7}{*}{ K- } & $0\left(25^{\circ} \mathrm{C}\right)$ & 1 & Putih & Khas & Lembut & Semi padat \\
\hline & 1 & 2 & Putih & Khas & Lembut & Semi padat \\
\hline & 2 & 4 & Putih & Khas & Lembut & Semi padat \\
\hline & 3 & 6 & Putih & Khas & Lembut & Semi padat \\
\hline & 4 & 8 & Putih & Khas & Lembut & Semi padat \\
\hline & 5 & 10 & Putih & Khas & Lembut & Semi padat \\
\hline & 6 & 12 & Putih & Khas & Lembut & Semi padat \\
\hline
\end{tabular}

Keterangan :

FI : Formula krim kombinasi ekstrak daun jambu biji dan ekstrak umbi wortel (1:3)

F2 : Formula krim kombinasi ekstrak daun jambu biji dan ekstrak umbi wortel $(2: 2)$

F3 : Formula krim kombinasi ekstrak daun jambu biji dan ekstrak umbi wortel $(3: 1)$

$\mathrm{K}-$ : basis krim

Pembuatan ekstrak daun jambu biji dan pembuatan ekstrak umbi wortel pada penelitian ini dilakukan dengan metode maserasi menggunakan pelarut etanol $70 \%$. Rendemen ekstrak daun jambu biji yang dihasilkan sebesar 20,61\% dan rendemen ekstrak umbi wortel yang diperoleh sebesar 13,64\%. Pengamatan stabilitas krim dilakukan dengan metode cycling test, yaitu pada suhu $0^{\circ} \mathrm{C}$ dan $40^{\circ} \mathrm{C}$. Hasil pengamatan organoleptis krim dapat dilihat pada tabel II. Hasil pengujian homogenitas krim, pH, daya sebar dan daya lekat krim dapat dilihat pada tabel III. 
Tabel III. Hasil uji homogenitas, pH, daya sebar dan daya lekat krim

\begin{tabular}{|c|c|c|c|c|c|c|}
\hline \multirow[b]{2}{*}{ Sediaan } & \multirow[b]{2}{*}{ Siklus } & \multirow[b]{2}{*}{ Hari ke- } & \multicolumn{4}{|c|}{ Pengamatan } \\
\hline & & & Homogenitas & $\mathrm{pH}$ & $\begin{array}{l}\text { daya sebar } \\
(\mathrm{cm})\end{array}$ & $\begin{array}{c}\text { daya lekat } \\
\text { (detik) }\end{array}$ \\
\hline \multirow{7}{*}{$\mathrm{F} 1$} & $0\left(25^{\circ} \mathrm{C}\right)$ & 1 & Homogen & 5 & 4,5 & $00.04,43$ \\
\hline & 1 & 2 & Homogen & 5 & 2,1 & $00.08,48$ \\
\hline & 2 & 4 & Homogen & 5 & 4,3 & $00.04,27$ \\
\hline & 3 & 6 & Homogen & 5 & 4,7 & $00.01,80$ \\
\hline & 4 & 8 & Homogen & 5 & 5,3 & $00.03,75$ \\
\hline & 5 & 10 & Homogen & 7 & 3,0 & $00.01,91$ \\
\hline & 6 & 12 & Homogen & 7 & 4,3 & $00.03,85$ \\
\hline \multirow{7}{*}{$\mathrm{F} 2$} & $0\left(25^{\circ} \mathrm{C}\right)$ & 1 & Homogen & 5 & 4,0 & $00.08,36$ \\
\hline & 1 & 2 & Homogen & 5 & 2,2 & $00.01,42$ \\
\hline & 2 & 4 & Homogen & 5 & 3,7 & $00.06,36$ \\
\hline & 3 & 6 & Homogen & 5 & 3,0 & $00.05,94$ \\
\hline & 4 & 8 & Homogen & 5 & 3,7 & $00.02,35$ \\
\hline & 5 & 10 & Homogen & 5 & 3,2 & $00.02,21$ \\
\hline & 6 & 12 & Homogen & 6 & 3,8 & $00.09,49$ \\
\hline \multirow{7}{*}{ F3 } & $0\left(25^{\circ} \mathrm{C}\right)$ & 1 & Homogen & 5 & 4,5 & $00.13,74$ \\
\hline & 1 & 2 & Homogen & 5 & 5,3 & $00.03,67$ \\
\hline & 2 & 4 & Homogen & 5 & 5,2 & $00.02,20$ \\
\hline & 3 & 6 & Homogen & 5 & 4,6 & $00.02,14$ \\
\hline & 4 & 8 & Homogen & 5 & 3,7 & $00.06,66$ \\
\hline & 5 & 10 & Homogen & 5 & 4,8 & $00.01,98$ \\
\hline & 6 & 12 & Homogen & 6 & 4,5 & $00.06,22$ \\
\hline \multirow{7}{*}{ K- } & $0\left(25^{\circ} \mathrm{C}\right)$ & 1 & Homogen & 5 & 5,5 & $00.05,03$ \\
\hline & 1 & 2 & Homogen & 5 & 2,3 & $00.02,17$ \\
\hline & 2 & 4 & Homogen & 5 & 5,1 & $00.02,74$ \\
\hline & 3 & 6 & Homogen & 5 & 4,3 & $00.03,21$ \\
\hline & 4 & 8 & Homogen & 5 & 3,3 & $00.06,74$ \\
\hline & 5 & 10 & Homogen & 5 & 2,6 & $00.01,02$ \\
\hline & 6 & 12 & Homogen & 6 & 4 & $00.03,59$ \\
\hline
\end{tabular}

Keterangan :

FI : Formula krim kombinasi ekstrak daun jambu biji dan ekstrak umbi wortel (1: 3)

F2 : Formula krim kombinasi ekstrak daun jambu biji dan ekstrak umbi wortel $(2: 2)$

F3 : Formula krim kombinasi ekstrak daun jambu biji dan ekstrak umbi wortel $(3: 1)$

$\mathrm{K}-$ : basis krim

Selama periode cycling test, krim kombinasi ekstrak daun jambu biji dan ekstrak umbi wortel FI, FII, FIII maupun basis krim selama periode cycling test mempunyai daya sebar antara 2,1-5,5 cm, nilai ini naik turun dan cenderung tidak memenuhi persyaratan daya sebar untuk sediaan topikal yang baik yaitu sekitar 5-7 cm (Garg dkk, 2002). Pada formula II daya sebar dari hari ke nol tidak memenuhi persyaratan daya sebar. Pengujian hari ke nol, suhu $25^{\circ} \mathrm{C}$ daya sebar basis krim masih memenuhi syarat, perubahan suhu ekstrim $0^{\circ} \mathrm{C}$ dan $40^{\circ} \mathrm{C}$ mempengaruhi viskositas basis sehingga terjadi penurunan dan kenaikan daya sebar pada basis krim. Selanjutnya uji daya lekat, syarat waktu daya lekat yang baik untuk sediaan topikal adalah tidak kurang dari 4 detik (Ulaen dkk., 2012) sehingga untuk sediaan krim kombinasi ekstrak daun jambu biji dan ekstrak umbi wortel memenuhi persyaratan uji daya lekat karena berkisar antara 4-13 detik. 
Nilai pengukuran $\mathrm{pH}$ sediaan baik formula I, II atau III dan basis krim (K-) memenuhi persyaratan $\mathrm{pH}$ sediaan topikal kulit yaitu 4,5-6,5. Nilai $\mathrm{pH}$ yang kurang dari 4,5 dapat mengiritasi kulit sedangkan $\mathrm{pH}$ lebih dari 6,5 dapat mengakibatkan kulit bersisik. Pengujian viskositas terhadap formula krim I, II, dan III dan basis krim memenuhi persyaratan karena viskositas sediaan topikal yang baik yaitu kurang dari 4000-40.000 centipoise (Wasiaatmaja, 1997). Hasil pengujian viskositas krim dapat dilihat pada tabel IV.

Tabel IV. Hasil uji viskositas sediaan

\begin{tabular}{|c|c|}
\hline Sediaan & Viskositas (Poise) \\
\hline F1 & $4,30 \pm 0$ \\
\hline F2 & $4,24 \pm 1,15$ \\
\hline F3 & $4,05 \pm 0$ \\
\hline K- & $4,37 \pm 1,44$ \\
\hline
\end{tabular}

Keterangan :

FI : Formula krim kombinasi ekstrak daun jambu biji dan ekstrak umbi wortel (1:3)

F2 : Formula krim kombinasi ekstrak daun jambu biji dan ekstrak umbi wortel $(2: 2)$

F3 : Formula krim kombinasi ekstrak daun jambu biji dan ekstrak umbi wortel $(3: 1)$

$\mathrm{K}-$ : basis krim

Keempat formula krim (FI,F2,F3 dan basis krim) diuji aktivitas antioksidannya. Berdasarkan hasil penentuan panjang gelombang maksimum DPPH, diperoleh $\lambda$ maks 517 $\mathrm{nm}$, maka pengujian aktivitas antioksidan formula krim, $\mathrm{K}-$, dan vitamin $\mathrm{C}$ sebagai pembanding dilakukan pada pada panjang gelombang $517 \mathrm{~nm}$. Nilai $\mathrm{IC}_{50}$ dari formula krim tersebut dibandingkan dengan kontrol positif vitamin C. Hasil absorbansi, \%Inhibisi dan $\mathrm{IC}_{50}$ dapat dilihat pada tabel V. Data dihitung dengan menggunakan aplikasi SPSS versi 23 yang dapat menentukan persamaan garis regresi linier $y=b x+a$. Dari hasil perhitungan regresi linear seri konsentrasi vitamin $\mathrm{C}$ terhadap \% inhibisi diperoleh persamaan regresi $\mathrm{Y}=$ $2,289 x+19,701$ kemudian didapatkan hasil IC $_{50}$. Dari hasil perhitungan regresi linear seri konsentrasi formula I terhadap \% inhibisi diperoleh persamaan regresi $\mathrm{Y}=0,543 \mathrm{x}-5,763$. Dari hasil perhitungan regresi linear seri konsentrasi formula II terhadap \% inhibisi diperoleh persamaan regresi $Y=0,732 x-10,405$. Dari hasil perhitungan regresi linear seri konsentrasi formula I terhadap \% inhibisi diperoleh persamaan regresi $\mathrm{Y}=0,409 \mathrm{x}-0,490$. $\mathrm{IC}_{50}$ merupakan suatu parameter dalam penentuan aktivitas antioksidan, berupa konsentrasi zat antioksidan yang efektif untuk menghambat 50\% aktivitas radikal bebas DPPH (Molyneux, 2003). Dari hasil $\mathrm{IC}_{50}$ dapat di simpulkan bahwa krim kombinasi ekstrak daun jambu biji dan ekstrak umbi wortel mempunyai aktivitas sebagai antioksidan (penangkal radikal bebas). 
Tabel V. Uji Aktivitas Antioksidan Krim Kombinasi Ektrak Daun Jambu Biji Dan Ekstrak Umbi Wortel Dengan Menggunakan Metode DPPH

\begin{tabular}{ccccc}
\hline Sampel & $\begin{array}{c}\text { Konsentrasi } \\
\text { (ppm) }\end{array}$ & $\begin{array}{c}\text { Absorbansi } \\
\text { (ppm) }\end{array}$ & \% inhibisi & $\begin{array}{c}\mathbf{I C}_{\mathbf{5 0}} \\
\text { (ppm) }\end{array}$ \\
\hline \multirow{3}{*}{ F1 } & 10 & 0,516 & 3,73 & \\
& 20 & 0,510 & 4,85 & 102,69 \\
& 30 & 0,508 & 5,22 & \\
& 40 & 0,477 & 11,00 & \\
F2 & 50 & 0,387 & 27,79 & 82,52 \\
& 10 & 0,316 & 2,76 & \\
& 20 & 0,312 & 4,00 & \\
& 30 & 0,306 & 5,84 & 132,45 \\
F3 & 40 & 0,300 & 7,69 & \\
& 50 & 0,203 & 37,53 & \\
& 10 & 0,549 & 6,79 & \\
& 20 & 0,547 & 7,13 & \\
& 30 & 0,545 & 7,47 & \\
& 40 & 0,510 & 13,41 & \\
& 50 & 0,477 & 24,10 & \\
& 10 & 0,580 & 1,52 & \\
& 20 & 0,575 & 2,37 & \\
& 30 & 0,568 & 3,56 & \\
& 40 & 0,562 & 4,58 & \\
& 50 & 0,547 & 7,13 & \\
& 2 & 0,333 & 19,75 & \\
& 4 & 0,272 & 34,45 & \\
& 6 & 0,271 & 34,69 & \\
& 8 & 0,262 & 36,86 & \\
& 10 & 0,243 & 41,44 & \\
\hline
\end{tabular}

Keterangan :

FI : krim kombinasi ekstrak daun jambu biji dan ekstrak umbi wortel (1:3)

F2 : krim kombinasi ekstrak daun jambu biji dan ekstrak umbi wortel $(2: 2)$

F3 : krim kombinasi ekstrak daun jambu biji dan ekstrak umbi wortel $(3: 1)$

$\mathrm{K}-$ : basis krim

$\mathrm{K}+$ : Vitamin $\mathrm{C}$

Krim formula I memiliki aktivitas antioksidan sebesar 102,69 ppm, Formula II dengan konsentrasi ekstrak daun jambu biji dan ekstrak umbi wortel $(2 \%: 2 \%)$ memiliki aktivitas antioksidan sebesar 82,52 ppm, Formula III memiliki IC $_{50}$ sebesar 132,45 ppm, kontrol negatif memiliki $\mathrm{IC}_{50}$ sebesar $380,28 \mathrm{ppm}$, sedangkan untuk kontrol positif memiliki $\mathrm{IC}_{50}$ sebesar 13,32 ppm. Nilai IC $\mathrm{IC}_{50} 101-150 \mathrm{ppm}$ memiliki intensitas antioksidan sedang, dan $\mathrm{IC}_{50}$ 50-100 ppm menunjukkan intensitas antioksidan kuat (Armala, 2009). Rohman dkk menyatakan bahwa semakin kecil $\mathrm{IC}_{50}$ suatu senyawa uji maka senyawa tersebut semakin aktif sebagai penangkal radikal bebas (antioksidan). 


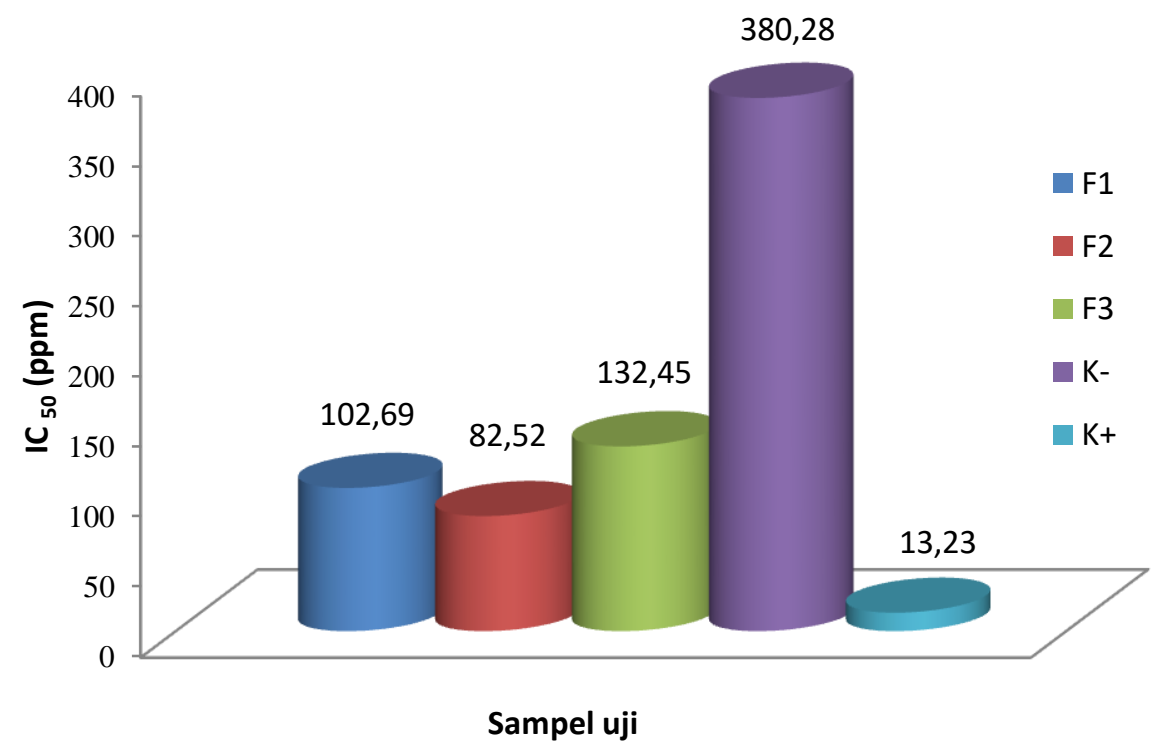

\footnotetext{
Keterangan :

FI : krim kombinasi ekstrak daun jambu biji dan ekstrak umbi wortel $(1: 3)$

F2 : krim kombinasi ekstrak daun jambu biji dan ekstrak umbi wortel $(2: 2)$

F3 : krim kombinasi ekstrak daun jambu biji dan ekstrak umbi wortel $(3: 1)$

$\mathrm{K}-$ : basis krim

$\mathrm{K}+$ : Vitamin C
}

Gambar 1. Hasil $\mathrm{IC}_{50}$ Krim Kombinasi Ekstrak Daun Jambu Biji Dan Ekstrak Umbi Wortel

\section{KESIMPULAN}

Krim kombinasi ekstrak daun jambu biji (Psidium guajava L) dan ekstrak umbi wortel (Daucus carota L) memiliki aktivitas antioksidan. Dari ketiga formula krim dinyatakan bahwa krim kombinasi ekstrak daun jambu biji (Psidium guajava L) dan ekstrak umbi wortel (Daucus carota L) pada Formula II dengan konsentrasi ekstrak daun jambu biji dan ekstrak wortel $(2 \%: 2 \%)$ memiliki aktivitas antioksidan tertinggi dengan nilai $\mathrm{IC}_{50}$ sebesar 82,52 ppm.

\section{DAFTAR PUSTAKA}

Armala, M.M. 2009. Daya antioksidan Fraksi Air Ekstrak Herba Kenikir (Cosmos caudatus H. B. K) dan profil KLT, Skripsi, 39, Fakultas Farmasi Indonesia Islam Indonesia, Yogyakarta

Andarwulan, N dan Koswara, S . 1992. Kimia Vitamin. Jakarta : Rajawali. Press Hal 25, 26, 33

Engelina, N.G. 2013. Optimasi Krim Sarang urung Walet Putih (Aerodramus fuciphagus) tipe M/A dengan variasi Emulgator Seagai Pencerah Kulit Menggunakan Simplex Lattice Design. Skripsi. Universitas Tanjungpura, Pontianak.

Garg, A., D. Aggarwal, S. Garg, and A. K. Sigla. 2002. Spreading of Semisolid Formulation: An Update. Pharmaceutical Tecnology. September: 84-102. 
Kokasih, E.N., Tony S., dan Hendro H (2006). Peran antioksidan pada lanjut usia. Pusat kajian Nasional Masalah Lanjut Usia. Jakarta, 48-49.

Maulina, I. D.2011.Uji Stabilitas Fisik Dan Aktivitas Antioksidan Sediaan Krim Yang Mengandung Umbi Wortel (Daucus carota L). Depok : Universitas Indonesia

Medical Economics Company. 2000. PDR For Herbal. 2nd Edition. New Jersey: Medical Economics Company

Molyneux, P. 2004. The use of the stable free radical diphenylpicryl-hydrazyl (DPPH) for estimating antioxidant activity. J. Sci. Technol., 26(2):211-219.

Prakash, A., Rigelhof, F dan Miller, E. 2001. Antioxydant Activity. Medallion Laboratories Analitycal progress. Vol. 10 No. 2

Suryani, Putri, A.E.P dan Fitrih, W. H,2013. Uji Aktivitas Antioksidan dan Stabilitas Fisik Gel Ekstrak Terpurifikasi Daun Jambu Biji (Psidium guajava L.). Majalah Farmasi, Sains, dan Kesehatan, Volume 1, No. 2, Hal. 43-48.

Ulaen, Selfie P.J., Banne, Yos Suatan \& Ririn A. (2012). Pembuatan Salep Anti Jerawat dari Ekstrak Rimpang Temulawak (Curcuma xanthorrhiza Roxb.), Jurnal Ilmiah Farmasi, 3(20, 45-49\

Winarsih, H. (2007). Antioksidan alami dan radikal bebas. Yogyakarta: Penerbit Kanisius.

Wasitaatmadja. 1997. Penuntun Kosmetik Medik, Universitas Indonesia, Jakarta. 